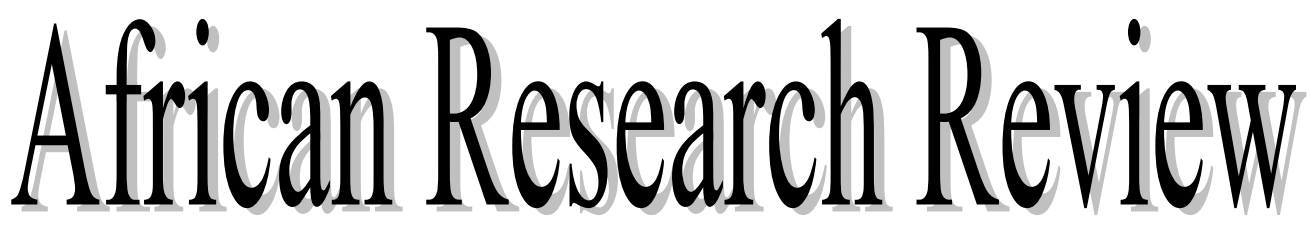

AN INTERNATIONAL MULTI-DISCIPLINARY JOURNAL,

BAHIR DAR, ETHIOPIA

AFRREV VOL. 11 (3), SERIAL NO. 47, JULY, 2017: 178-186

ISSN 1994-9057 (Print)

ISSN 2070-0083 (Online)

DOI : http://dx.doi.org/10.4314/afrrev.v11i3.17

\title{
Stock Walk with Consumable Deliverables: Association of Price and Dividend in the Nigerian Capital Market
}

\author{
Agundu, Prince Umor C. \\ Head, Department of Banking \& Finance \\ Federal University Wukari \\ Taraba State, Nigeria \\ E-mail: princeagundu@fuwukari.edu.ng \\ Phone: +2348037757642
}

\author{
Wula, James T. \\ Department of Accounting, \\ Federal University Wukari \\ Taraba State, Nigeria
}

\begin{abstract}
This study examined the relationship between stock price and dividend per share. In the analytical framework, dividend per share (the independent variable) serves as proxy for corporate financial performance, while stock price of consumer good firms listed on the Nigerian Stock Exchange (NSE) features as dependent variable. The baseline assumption is that investors rely on key financial indicators (KFIs) in making rational investment decisions. All 26 consumer good firms on the Daily Official List on 31st December, 2014 were eligible for involvement, by using a profit - dividend payment filter, $18(69 \%)$ of the firms selected. The panel data so harnessed covered a period of six years (2009-2014), and 108 observations were made. Data treatment methods include descriptive statistics, correlation and regression analyses, as well as t-test. The results established that stock price is significantly associated with dividend per share, at the 0.05 level. Against this concentric analytical outcome, it was recommended that investment analysts/managers should mine unfolding information to mind the dynamics of dividends, especially in the consumer goods market segment. In tracking and attracting greater competitive stock pricing fortunes, they should reengineer
\end{abstract}

Copyright () International Association of African Researchers and Reviewers, 2006-2017: www.afrevjo.net.

Indexed African Journals Online: www.ajol.info 
internal market mechanisms to strategically guard against scenic transaction pitfalls particularly in fragile trading settings.

Key Words: Dividend, Stock market, Prices

\section{Introduction}

Traditionally, dividend represents a portion of profit after tax that is distributed to shareholders for investing and bearing risk in a firm. It is the return that investors (shareholders) receive on their shareholdings and serves as a regular source of income. Investors who prefer current income (in the form of dividend) to capital appreciation, therefore, go for stocks that pay out higher dividends. This preference logically causes clamour for such stocks and the attendant soaring of their prices. In relative fundamental terms, dividend per share, the ratio of annual dividend amount paid equity shareholders to number of equity shares outstanding, is operationally apt for analysis, hence its adoption in this study. In recent times, capital market dynamics in Nigeria has profoundly substantiated stock price swings, visibly featuring random movements that culminate in return slides (Abosede \& Oseni, 2011). Recourse to these dynamics is integrally fundamental in fostering quality investment decisions, as shareholders strive to maximize expected return and minimize risk. In furtherance of these tendencies, the imperativeness of financial performance analysis cannot be over-emphasized.

Strategically, financial performance analysis involves evaluation of a firm's efficiency and effectiveness in generating revenue and utilizing information contained in the financial statements. By this, the economic strengths and weaknesses of a firm are revealed in order to establish relationships between various elements of the comprehensive income and financial position statements. The scope of financial reporting logically presents corporate fundamentals pertaining to an accounting period, which are usually harnessed in the computation of accounting ratios. The main ratios identified with the capital market include earnings per share, dividend per share, priceearnings ratio, book value per share, net assets per share, and dividend cover. Other market ratios underscored by capital market watchers include the Tobin Q and market value to book value ratios (Stephen \& Okoro, 2014; Jang \& Lee, 2010; Oyerinde, 2009; Wula, 2016).

Investors expect to earn attractive returns in their stock market investments hence they bring their perception of prevailing performance and unfolding prospects to bear on stock prices. In adjusting to stock prices, they identify critical factors that influence movements, which include dividend per share. In view of the criticality of reward for investing, this study examines the extent to which stock price is associated with dividend per share in consumer good firms listed on the Nigerian Stock Exchange (NSE). The research hypothesis elicited is:

$\mathbf{H}_{\mathbf{0}}$ : $\quad$ Share price is not significantly associated with dividend per share in consumer good firms listed on the NSE.

\section{Literature Review}

In an efficient market scenario, stock price anchors a critical measure of firm's performance and competitive value, thus, serving as basis for assessing corporate standing. It serves as one of the fundamental metrics of returns, with utmost value for the decisional purposes of substantive and prospective investors/stakeholders

Copyright (C) International Association of African Researchers and Reviewers, 2006-2017: www.afrrevjo.net.

Indexed African Journals Online: www.ajol.info 
(Almumani, 2014). The mechanisms entail assessing corporate policies, operations and general financial health over a period of time, which ensure commensurate returns for the rational investor. Managers, therefore, analyse firms' financial performance in order to reposition and improve on their overall competitiveness in the marketplace. They equally seek to identify opportunities for reinventing the performance of various departments, units or levels. At the end of operations, financial performance analysis is undertaken through meticulous collation, computation and communication of traditional accounting ratios, which include liquidity/working capital ratios, leverage/gearing ratios, turnover/profitability ratios, and investor/market ratios (Agundu, 2012). From the investment/capital market perspective, sensitivity of stock price cannot be over-emphasized, as it represents:

- the value at which a unit of stock could be traded,

- the highest amount an investor is willing to pay for a unit of stock, or

- the lowest amount a unit of stock could be sold (divested).

Theoretically, random walk analytical techniques facilitate the modelling of stock price behaviour, alongside the dynamics of currency exchange rates and commodity prices. This is with the assumption that investors are rational and bias free. To this end, all existing information affects stock prices, such that change in behaviour occurs when new information rolls in and takes its toll on market forces. Regarding the value relevance of accounting information, dividend per share particularly has the ability to exhibit features that affect a firm's value, thus contributing to measurement of aggregate market impact. Financial analysts argue that value relevance ideals bear critically on the quality and usefulness of accounting data (Klimczak, 2009). They seek to:

- ascertain whether accounting earnings are relevant in the valuation of stock market equities; and

- compare the results of (1) above with scholarly findings from other (advanced) climes.

Nonetheless, analysts also consider tangibility of assets, change in growth opportunities, profitability, and liquidity of the firm, while some others underscore change in dividend policy, size of the firm, and leverage, which are apparently positively related with stock prices (Wula, 2016). In a study involving 99 firms listed on the NSE, cutting across all sectors of the economy (over the period 2001-2011), Stephen \& Okoro (2014) sought to identify critical determinants of stock price movements in Nigeria. They applied the ordinary least squares (OLS) technique to track the impact of market fundamentals on stock prices. Whereas the Ohlson's (1995) model expresses stock price as a function of earnings per share and book value per share, they operationally extended the framework to encapsulate dividend cover as a third parameter, giving rise to recognition and designation of the integrated Ohlson's model. Concerned with the contributory influence of the third correlate, this study examines the association of stock price with dividend per share in consumer good firms listed on the NSE. 


\section{Methods}

The population of this study comprises all 26 consumer good firms on the Daily Official List on 31st December, 2014. Using a profit - dividend payment filter, firms that did not make profit or those that made profit but did not declare dividends in the period are excluded. This gives a sample size of 18 firms, representing $69 \%$ of the population. This is well accommodated within the framework of Krejcie \& Morgan (1970), which stipulates a minimum sample size of $50 \%$ of a defined population to be adopted for the purpose of generalization. Panel data, representing a combination of time series with cross-sectional submissions over a six-year period (2009-2014), are harnessed for the study. By this, every firm in the sample had the same number of observations, giving 108 observations (derived as product of 18 sample firms and six years). In analysing the data, the statistical proceedings involve:

- descriptive statistics, which provide simple summaries about the variables;

- correlation analysis, which determines the degree and direction of association among the variables; and

- regression analysis, which reveals predictive variable(s) and makes for more accurate functional modelling.

The statistical treatment of the research hypothesis involves t-test, which is justified by a sample size less than 30 (Gujarati \& Porter, 2009; Nsude, 2005). An over-arching framework in this regard recognizes the potency of three fundamental variables, namely, dividend per share, earnings per share, and price-earnings ratio. Where stock price is jointly and severally associated, the composite model specification is as follows:

Stpri $_{t}=f\left(\right.$ Divps $_{t}$, Earps $_{t}$, Prear $\left._{t}, e_{t}\right)$

Where:

$S t p r i_{i t}=$ Stock Price measured as average yearly market price of shares,

Divps $_{i t}=$ Dividend per share measured as declared dividend divided by outstanding ordinary shares,

Earps $_{i t}=$ Earnings per share measured as earning divided by outstanding ordinary Shares,

Prear $_{i t}=$ Price-earnings ratio measured as market price of shares divided by earnings per share,

$e_{i t}=$ Error term or residuals in the model (used to capture all other variables not included in the model),

$t \quad=$ Time dimension of the variables

$\beta_{0}=$ Constant or intercept, and

$\beta_{1-3}=$ Coefficients to be estimated or the Coefficients of slope parameters

Model specification (1) is expanded thus:

Stpri $_{i t}=\beta_{0}+\beta_{1}$ Divps $_{i t}+\beta_{2}$ Earps $_{i t}+\beta_{3}$ Prear $_{i t}+e_{i t}$

Model expansion (2) is operationally distilled thus:

Stpri $_{t}=f\left(\right.$ Divps $\left._{t}\right)$

Copyright $\left({ }^{\circ}\right.$ International Association of African Researchers and Reviewers, 2006-2017: www.afrevjo.net.

Indexed African Journals Online: www.ajol.info 
These functional formations are methodologically identified with the investigations earlier conducted by Almumani (2014), Srinivasan (2012), and Sharma (2011).

\section{Results}

Furthering the research process, analysis of data commences with descriptive statistics on the focal variables, in order to reveal their mean, standard deviation, minimum and maximum values. With the normalization of the statistical distribution, Pearson product-moment correlation method is employed in assessing the degree of association between stock price and dividend per share; while the research hypothesis is t-tested at 0.05 level of significance. The statistical results are presented in Tables 2, 3, and 4; after the sampled firms are highlighted in Table 1:

Table 1: Listed Firms Selected for the Study

\begin{tabular}{rlll}
\hline \multicolumn{1}{c}{ S/NO } & \multicolumn{1}{c}{ NAME OF FIRM } & \multicolumn{1}{c}{ SUB-SECTOR } & REMARK \\
\hline 1 & 7-Up Bottling Company Plc & Beverages Non-Alcoholic & Sampled \\
2 & Guinness Nigeria Plc & Beverages Brewers/Distillers & Sampled \\
3 & Nigerian Breweries Plc & Beverages Brewers/Distillers & Sampled \\
4 & Dangote Sugar Refinery Plc & Food Products & Sampled \\
5 & Flour Mills of Nigeria Plc & Food Products & Sampled \\
6 & Honeywell Flour Mills Plc & Food Products & Sampled \\
7 & Northern Nigeria Flour Mills Plc & Food Products & Sampled \\
8 & NASCON Allied Industries Plc & Food Products & Sampled \\
9 & Dangote Flour Mills & Food Products & Sampled \\
10 & UTC Nigeria Plc & Food Products & Sampled \\
11 & P.S. Mandrides Co. & Food Products & Sampled \\
12 & Nestle Nigeria Plc & Food Products Diversified & Sampled \\
13 & Cadbury Nigeria Plc & Food Products Diversified & Sampled \\
14 & Vono Products & Household Durables & Sampled \\
15 & Nigerian Enamelware Plc & Household Durables & Sampled \\
16 & Vitafoam Nigeria Plc & Household Durables & Sampled \\
17 & PZ Cussons Nigeria Plc & Personal Household Products & Sampled \\
18 & Unilever Nigeria Plc & Personal Household Products & Sampled \\
\hline
\end{tabular}

Source: NSE Daily Official List 2014

Table 2: Descriptive Statistical Highlights

\begin{tabular}{|lcccc|}
\hline Variable & Mean & $\begin{array}{c}\text { Standard } \\
\text { Deviation }\end{array}$ & Minimum & \multicolumn{1}{l|}{ Maximum } \\
\hline Stpri & 69.42 & 151.19 & 0.60 & 982.81 \\
Divps & 2.42 & 4.72 & 0.01 & 27.50 \\
Earps & 3.24 & 5.53 & 0.03 & 28.10 \\
Prear & 23.65 & 33.37 & 2.40 & 290.33 \\
\hline
\end{tabular}

Source: Research Data (Stata 12 Output)

Copyright (C) International Association of African Researchers and Reviewers, 2006-2017: www.afrrevjo.net. 
Table 3: Correlation Matrix Statistics

\begin{tabular}{|c|c|c|c|c|c|}
\hline Variables & Statistics & logStpr & logDivps & logEarps & logPrear \\
\hline LogStpri & $\begin{array}{l}\text { Pearson correlation } \\
\mathrm{N}\end{array}$ & $\begin{array}{l}1.0000 \\
108\end{array}$ & & & \\
\hline LogDivps & $\begin{array}{l}\text { Pearson correlation } \\
\text { Sig. 2-tail } \\
\text { N }\end{array}$ & $\begin{array}{l}0.772 * * \\
0.000 \\
108\end{array}$ & $\begin{array}{l}1.0000 \\
108\end{array}$ & & \\
\hline
\end{tabular}

Table 4: Hypothesis Test Statistics

\begin{tabular}{|lccc|}
\hline $\begin{array}{l}\text { STATISTICS } \\
\text { VARIABLES }\end{array}$ & COEFFICIENTS & t-VALUE & SIGNIFICANCE \\
\hline logDivps & 0.164 & 3.00 & 0.004 \\
\hline
\end{tabular}

Source: Research Data (Stata 12 Output)

From Table 2, the average stock price for the sampled firms during the six-year period is 69.42. The standard deviation of 151.19 centrally indicates the magnitude by which stock price varies. The mean dividend per share of $\$ 2.42$ with a standard deviation of 4 .72, also centrally indicates the magnitude by which dividend per share varies among the firms. The results in Table 2 indicate that the variables have correlation coefficient of 0.772 , indicating significant relationship between stock price and dividend per share at 0.01 . More fundamentally, from Table 3, the coefficient of dividend per share is positive and significant at 0.05 . Given that the coefficient is different from zero; and calculated t-value is higher than the critical value, the null hypothesis is rejected and the alternate upheld, affirming that stock price is significantly associated with dividend per share.

\section{Discussion}

The statistical results from the analysis segment vividly indicate a positive and significant association between stock price and dividend per share. This implies that stock prices rise with increase in dividend payments, which ultimately increases shareholder value. Thus, when firms effect payment of cash dividend or withhold payment, it exerts critical influence on stock price behaviour and volumetric dynamics. By this, the alternate hypothesis is upheld that stock price is significantly associated with dividend per share in consumer good firms listed on the NSE. Regarding the ideals of fundamental (intrinsic value) analysis, market watchers admit that earnings and dividend prospects critically determine stock prices. The investigations conducted by Srinivasan (2012), Khan (2009), and Stephen \& Okoro (2014) had earlier categorically established a significant relationship between share price and dividend payments. However, the outcome of the studies carried out by Gharaibeh (2015) and Almumani (2014) was non-affirmative.

This study covers a period of six years from 2009-2014, a period in which the Nigerian capital market recorded very low activity, particularly sharp drop in share prices

Copyright () International Association of African Researchers and Reviewers, 2006-2017: www.afrevjo.net. 
following the 2008 global stock crash. This period was also crucial in the analysis in view of the desire to ascertain the extent to which critical correlates (fundamentals) affect post-crash stock prices in the market. The period equally marked the introduction of the NSE 30 Index, and the era in which the NSE projected five-sector indices as investable benchmarks for the performance of specific sectors in the economy (NSE 2011/2012; Wula, 2016).

\section{Conclusion}

The findings of this study, substantiated by the statistical results, establish a positive and significant association between stock price and dividend per share in consumer good firms listed on the NSE. Impliedly, stock price rises as dividend per share increases, making investors to rationally and logically attach high premium on the regularity and intensity of dividend payments. Apparently, investors still harness current income in the form of dividend as preferred option in optimizing market dynamics. Even where earnings remain the same, stock price tends to increase as dividend payment increases. These behavioural dynamics affirm the potentiality of dividends in:

- reducing the risk (uncertainty) attached to shares,

- reliving the psychological preference of investors for current rather than future earnings; and

- revealing the information content bordering on corporate earnings capacity.

Financial performance evaluation, besides profitability analysis, extends to concerns bordering on the outcomes of working capital/liquidity analysis, financial structure analysis, activity analysis and market value/investment ratio analysis. This study anchors on market value/investor ratios with strategic focus on dividend per share. It contextually addresses long-term financial performance and buttreses income in relation to degree of satisfaction of investors (shareholders). This fundamentally accentuates the concept of value relevance in accounting/financial reporting, the primordial conceptualization of which is the association between accounting information and security market values (Amir, Harris \& Venuti, 1993). Furthermore, it projects the ability of financial statements to encapsulate a firm's value in terms of the statistical association between financial statement information and stock market values. Consequently, financial statements users are enabled to determine more realistically the value and performance of firms (Beisland (2009; Oyerinde, 2011). In their contribution, Francis \& Schipper (1999) identify the functional perspectives of value relevance as:

- estimation, whereby financial statement information affects stock prices through the capture of intrinsic stock values;

- prediction, whereby financial information contains the variables that assist in modelling other variables; and

- association, whereby financial information exhibits statistical relationship with stock prices or returns.

In the light of the study outcomes, it is recommended that investment managers, especially in the consumer goods market constituency, should strategically drill the

Copyright (C) International Association of African Researchers and Reviewers, 2006-2017: www.afrrevjo.net.

Indexed African Journals Online: www.ajol.info 
insightful analytical revelations and strive towards greater efficiency in dividend management and administration. They should pragmatically forge better stock pricing regimes to reinvent their corporate profiles in the comity of market institutions.

\section{References}

Abosede, A. J. \& Oseni, J. E. (2011). Theoretical analysis of firm and market-specific proxies of information asymmetry on equity prices in the stock markets. Australian Journal of Business and Management Research, 1(2), 1-13.

Almumani, M. A. (2014). Determinants of equity share prices of the listed banks in Amman Stock Exchange: Quantitative Approach. International Journal of Business and Social Science, 5(1), 91-104.

Agundu, P. U. C. (2012). Vintage: Strategic Financial Management. Port Harcourt: MPP.

Amir, E., Harris, T. S., \& Venuti, E. K. (1993). A comparison of the value-relevance of US versus non-U.S. GAAP accounting measures using Form 20-F reconciliations. Journal of Accounting Research, 31, 230-264.

Beisland, L. A. (2009). A review of the value relevance literature. The Open Business Journal, 2, 7-27.

Francis, J. \& Schipper, K. (1999). Have financial statements lost their relevance? Journal of Accounting Research Supplement, 37(12), 319-352.

Gharaibeh, A. M. O. (2015). The determinants of common share prices: New empirical evidence from Kuwait. EPRA International Journal of Economic and Business Review, 3(11), 28-40.

Gujarati, D. N. \& Porter, D. C. (2009). Basic Econometrics. Boston: McGraw-Hill.

Jang, J. I. \& Lee, K. J. (2010). Inter-temporal and cross-sectional variation in the value relevance of earnings and equity book value for Korean firms, PanPacific Journal of Business Research, 1(1), 4-15.

Karunarathne, W. \& Rajapakse, R. (2010). Value relevance of financial statement information with special reference to the listed companies in Colombo Stock Exchange, University of Kelaniya, Sri-Lanka.

Kendall, M. G. (1953). The analysis of economic time series. Journal of Royal Statistical Association, 11-25.

Khan, S. H. (2009). Determinants of share price movements in Bangladesh: Dividends and retained earnings (Unpublished MSc Thesis), School of Management, Blekinge Institute of Technology, 1-48.

Klimczak, K. M. (2009). Testing value relevance of accounting earnings in emerging markets. Retrieved from http://kmklim.republika.pl/ekonomia/resource/kmklimczak GAT 2008.pdf on January 18, 2016.

Krejcie, R. V. \& Morgan, D. W. (1970). Determining sample size for research activities. Educational and psychological measurement, 30, 607-610.

Copyright (ㅇ International Association of African Researchers and Reviewers, 2006-2017: www.afrrevjo.net.

Indexed African Journals Online: www.ajol.info 
Nigerian Stock Exchange (2011/2012). The Nigerian stock exchange Factbook. Abuja, Nigeria:

Nigerian Stock Exchange (2014). Daily Official List. Abuja, Nigeria

Nsude, F. I. (2005). Fundamental of statistics for business. (2nd ed.). Enugu: CIDJAP.

Ohlson, J. A. (1995). Earnings, book values, and dividends in equity valuation. Contemporary Accounting Research, 11, 661-87.

Oyerinde, D. T. (2011). Value relevance of accounting information in the Nigerian stock market (Unpublished PhD Thesis), Covenant University, Ota, Nigeria.

Sharma, S. (2011). Determinants of equity share prices in India. Journal of Arts, Science \& Commerce, 2(4), 51-60.

Srinivasan, P. (2012). Determinants of equity share prices in India: A panel data approach. The Romanian Economic Journal, 15(46), 205-228.

Stephen, E. A. \& Okoro, E. G. (2014). Determinants of stock price movement in Nigeria: Evidence from the Nigerian Stock Exchange. Journal of Economics and Sustainable Development, 5(3), 1-7.

Wula, J. T. (2016). Effects of financial performance on share price of listed consumer goods firms in Nigeria (Unpublished MSc Thesis). Makurdi, Nigeria: Benue State University, 